\title{
ブドウ球菌のウサギ皮内感染における免疫の機序
}

\section{1. .ブドウ球菌感染における血中抗体と皮膚反応の消長について}

\author{
沢井芳男石井卓弥 \\ 東京大学伝染病研究所試験製造室 (主任: 沢井芳男助教授)
}

[受付 : 7 月 12 日, 1965年]

\section{まえがき}

ブドウ球菌感染に際し免疫と同時にある種のアレルギ 一が成立することはこれまで知られている。 Panton お よび Valentine ${ }^{1)}(1920)$ はウサギの皮下感染において, 注射をくりかえしていくと膿瘍の縮小と同時に最少感染 量が減少していくことを指摘した。Boe ${ }^{2)}$ (1945) はワク チン注射により感作されたウサギにブドウ球菌の培養濾 液を注射することにより脱感作し得ることをのべた。ま た Forney ${ }^{3)}$ (1954) は結核菌の wax とブドウ球菌を混 合してモルモットに注射することにより遅延性のアレル :ギーの起るのを認めた。Prigal 等4)(1956) は牛血清と 百日咳ワクチンの前処置により感作をうけたマウスに牛 血清とブドウ球菌を混合してモルモットに注射してショ ックを起させるとブドウ球菌の体内分布が増強されるこ と等から hetero allergy の成立することを指摘した。

われわれもヒトのブドウ球菌感染症の治療にトキソイ ドが用いられる場合に，患者により皮膚反応に著しい相 “異のあることを認め，またトキソイドの治療効果が迅速 であることから，単なる免疫では説明し難い点があるの で今回はまず感染あるいは感作をうけたウサギの皮内反 応あるいは血中抗体がどの様に消長するかについて検討 を試みた。

\section{実験材料および実験方法}

実験動物 : 健康ウサギの体重 3 3.5kg, マウスは dd $4 \mathrm{w}$ を用いた。菌液：込宮株の 24 時間培養菌で感作お よび感染防御試験に用いた。マウスに対する感染防禦能 の測定法 : 各種免疫群のウサギの追加免疫 3 回接種後一 部試血を行、血清分離非仂化 $\left(56^{\circ} \mathrm{C} 30\right.$ 分）後強毒込宮 生菌 $1 \mathrm{mg}$ (2MLD) を等量加え $37^{\circ} \mathrm{C} 1$ 時間放置した後 ママウスの腹腔内に攻撃した。また対照血清として本室保
存の血清が用いられた。抗毒素価の測定法 : 非仂化した 被検血清の 各倍数稀䣋の $0.5 \mathrm{ml}$ を 1 列の 小試験管にと り, 次に最少溶血価 (MHD) の $0.5 \mathrm{ml}$ 中に $2 \sim 4 \mathrm{MHD}$ を含む様に 生理食塩水を以て稀䣋，その $0.5 \mathrm{ml}$ を上記 試験管に添加よく混和し， $37^{\circ} \mathrm{C} 30$ 分放置した後，1\% ウサギ血球浮游液を加え, $37^{\circ} \mathrm{C} 1$ 時間作用せしめ溶血 を阻止し得た被検血清の最大稀䆏倍数を求めた。これと 同時に対照として 1 単位の標準抗毒素を倍数稀釈し各稀 釈液の $0.5 \mathrm{ml}$ を 1 列の小試験管にとり，このものに上 記実験に使用した試験毒素液を加え同様な実験を行い完 全溶血を示した試験管中最大量の標準抗毒素含有管の示 す抗毒素価を以て, 試験毒素の LH 值とした。この LH 值より被検血清の力価を計算した。（溶血を阻止得を被 検血清の 最大稀釈倍数が標準血清の $\mathrm{LH}$ 量の 稀釈倍数 に等しい場合に 1 単位とする) 凝集価の測定法 : 被検血 清の 2 倍稀採系列を作り 24 時間培養菌の $1 \mathrm{mg} / \mathrm{ml}$ 菌液を 等量加えよく混和し $37^{\circ} \mathrm{C} 2$ 時間, ついで泠蔵庫に翌日ま でおいて判定した。免疫処置：ウサギの皮下に $1 \%$ ク口 トン油 $1.0 \mathrm{ml}$ を注射し 1 週間放置して得た無菌膿湟に 込宮株生菌 $2 \mathrm{mg} / 0.5 \mathrm{ml}$ を 1 週間隔で 4 回接種した。対 照として同株より作られたトキソイド（2 単位）あるい はホルマリンワクチン（菌量 $2.5 \mathrm{mg}$ ) を等量の Freund incomplete Adjuvant と混合し $2.5 \mathrm{ml}$ ないし $5 \mathrm{ml}$ をそ れぞれの両大腿部に筋注し， 3 週間放置後に追加注射と して前者は 1 週抒きに $2.5 \mathrm{ml}, 5 \mathrm{ml}, 5 \mathrm{ml}, 8 \mathrm{ml}$ の単味卜 キソイドを皮下へ，また後者には $5 \mathrm{mg}, 15 \mathrm{mg}$ を皮下に $7 \mathrm{mg}, 15 \mathrm{mg}$ を静脈内に行つた。免疫経過中には $\alpha$ 溶 血素価および凝集価を測定し，皮膚反応としてはウサギ の耳の皮下にトキソイド $0.05 \mathrm{ml}$ (LB 価 1 単位) を注射 した。またこれ等のウサギの血清の感染防禦能を前報5) と同様な方法で検査し，また直接生菌攻撃または毒素攻 撃を行つて防禦能をしらべた。 
表 1 各種免疫処置による皮膚反応および血中抗体の消長

\begin{tabular}{|c|c|c|c|c|c|c|c|c|}
\hline 免疫群 & $\begin{array}{c}\text { ウサギ } \\
\text { No. }\end{array}$ & 1 週 & 2 週 & 3 週 & 4 週 & 5 週 & 6 週 & 7 週 \\
\hline $\begin{array}{l}\text { 生 } \\
\text { 菌 } \\
\text { 免 } \\
\text { 疫 } \\
\text { 群 }\end{array}$ & $\begin{array}{l}16 \\
17 \\
18 \\
19 \\
20\end{array}$ & $\begin{array}{c}* 4+1 \mathrm{u} \\
8+^{1 / 4} \\
4+^{1 / 2} \\
2+1 / 2 \\
2+1 / 4\end{array}$ & $\begin{array}{l}8 H^{2} 2^{u} \\
8 W^{1 / 2} \\
4 H^{2} \\
4 H_{2} 2 \\
8 H_{1}\end{array}$ & $\begin{array}{l}32+2^{\mathrm{u}} \\
32+4 \\
32+8 \\
32+2 \\
32+4\end{array}$ & $\begin{array}{c}32+2^{\mathrm{u}} \\
\text { 死 } \\
64+8 \\
32+2 \\
64+4\end{array}$ & & & \\
\hline 死 & 1 & & & $6+1 / 16$ & $16+1 / 4$ & $16 \pm^{1 / 2}{ }^{\mathrm{u}}$ & $32 \pm 2^{\text {e }}$ & $64 \pm 2^{\mathrm{u}}$ \\
\hline & 2 & & & $8 W^{1 / 2}$ & $16 H^{1 / 2}$ & $16+2$ & $32+4$ & $64+4$ \\
\hline 菌 & 3 & & & $16 W^{1 / 2}$ & $16+4$ & $16+4$ & $32+4$ & $64+4$ \\
\hline & 4 & & & $8 H^{1} / 4$ & 16 H 2 & $32+4$ & $64+4$ & $64+4$ \\
\hline 免 & 5 & & & $16+1 / 4$ & $16+1$ & $16+2$ & $32 \pm 2$ & $64 \pm 2$ \\
\hline & 6 & & & $16+1 / 8$ & $16+1$ & $15+1$ & $32+2$ & $64 \pm 2$ \\
\hline 疫 & 7 & & & $16 W^{1 / 4}$ & $16+1$ & $16+2$ & 死 & \\
\hline 设 & 8 & & & $8+1 / 8$ & $16+1$ & $16+2$ & $32+2$ & $64+2$ \\
\hline 群 & 9 & & & $8 W^{1 / 4}$ & $16 \# 2$ & $16+2$ & $32+2$ & $64+2$ \\
\hline 研 & 10 & & & $8 W^{1} / 2$ & 8 \# 2 & $16+4$ & $32+4$ & $64+4$ \\
\hline 卜 免 & 11 & & & $4 \pm 1$ & $4 \pm 4$ & 4 H 4 & $8+2$ & $8+2$ \\
\hline キ & 12 & & & $4 \pm 1$ & $4+8$ & $4+8$ & $8+4$ & $8+2$ \\
\hline ソ 疫 & 13 & & & $4 \pm 2$ & $4 \pm 8$ & $4+8$ & $8+4$ & $16+2$ \\
\hline 1 & 14 & & & $4 \pm 2$ & $4 \pm 4$ & $8+4$ & $16+2$ & $16+1$ \\
\hline ド 群 & 15 & & & $4 \pm 2$ & $4+8$ & $4+8$ & $8+4$ & $8+2$ \\
\hline
\end{tabular}

* 左側数字ぱ凝集価(単位百), 右側は抗毒価, 卅は強度, 一は中等度, 十は軽度と皮膚反応の 強弱を示した.

表 2 免疫ウサギ血清によるマウスの感染防禦試験

\begin{tabular}{|c|c|c|c|c|c|c|c|}
\hline 免 疫 群 & ウサギNo. & 抗 毒 価 & 凝 集 価 & 免 疫 群 & ウサギNo & 抗 毒 価 & 凝集 価 \\
\hline \multirow[b]{2}{*}{ 死 } & 1 & $2 \mathrm{u}$ & $1: 3200$ & 卜 免 & 11 & $2^{\mathrm{u}}$ & $1: 800$ \\
\hline & 2 & 4 & $1: 3200$ & キ & 12 & 4 & $1: 800$ \\
\hline \multirow{2}{*}{ 菌 } & 3 & 4 & $1: 3200$ & ソ 疫 & 13 & 4 & $1: 800$ \\
\hline & 4 & 4 & $1: 6400$ & 1 & 14 & 2 & $1: 1600$ \\
\hline \multirow{3}{*}{ 免 } & 5 & 2 & $1: 3200$ & ト 群 & 15 & 4 & $1: 8000$ \\
\hline & 6 & 2 & $1: 3200$ & 生 & 16 & 2 & $1: 3200$ \\
\hline & 8 & 2 & $1: 3200$ & 菌 & 17 & 4 & $1: 3200$ \\
\hline 疫 & 9 & 2 & $1: 3200$ & 免 & โ8 & 8 & $1: 3200$ \\
\hline \multirow[t]{2}{*}{ 群 } & 10 & 4 & $1: 3200$ & 疫 & 19 & 2 & $1: 3200$ \\
\hline & & & & 群 & 20 & 4 & $1: 3200$ \\
\hline $\begin{array}{l}\text { 込宮株血 } \\
\text { 清 (対照) }\end{array}$ & . & 1 & $1: 12800$ & $\begin{array}{l}\text { 寺島株血 } \\
\text { 清 (対照) }\end{array}$ & & 1 & $1: 12800$ \\
\hline
\end{tabular}

\section{実 験 成 績}

血中抗体価と皮膚反応の推移 : 表 I に示された様に生 菌感染群では 2 週後に皮膚反応が最高, 最強となり以後 漸次減弱した。これに対して血中の抗毒素あるいは凝集
素は感染後 $4 \sim 5$ 週で最高になつた。一方においてトキ ソイド免疫群では皮膚反応は免疫 5 週で最高となつたが 大部分は中等ないし軽度の陽性を示した。血中抗毒素価 は既に 4 週で最高值に達したが，凝集素価は低かつた。 またワクチン免疫群では皮膚反応は免疫 3 週で最高に達 
表 3 免疫ウサギの感染防禦能および毒素中和能

生 菌 攻 撃*

\begin{tabular}{|c|c|c|c|c|}
\hline 免 疫 群 & $\begin{array}{c}\text { ウサギ } \\
\text { No }\end{array}$ & $\mid \begin{array}{l}\text { 死亡おょ } \\
\text { び 時 間 }\end{array}$ & $\begin{array}{l}\text { 攻撃時 } \\
\text { 抗毒価 }\end{array}$ & $\begin{array}{l}\text { 抗毒 時 } \\
\text { 凝集 価 }\end{array}$ \\
\hline \multirow{5}{*}{ 死菌免疫群 } & 1 & $+24^{\mathrm{h}}$ & $2^{u}$ & $1: 6,400$ \\
\hline & 2 & 生 & 4 & $1: 6,400$ \\
\hline & 3 & 生 & 4 & $1: 6,400$ \\
\hline & 4 & +48 & 4 & $1: 6,400$ \\
\hline & 5 & 生 & 2 & $1: 6,400$ \\
\hline \multirow{2}{*}{$\begin{array}{l}\text { トキソイド } \\
\text { 免 疫 群 }\end{array}$} & 11 & +72 & 2 & $1: 800$ \\
\hline & 12 & +48 & 2 & $1: 800$ \\
\hline \multirow{2}{*}{ 生菌免疫群 } & 16 & +72 & 2 & $1: 3,200$ \\
\hline & 18 & 生 & 8 & $1: 6,400$ \\
\hline \multirow{2}{*}{ 無 処 置 群 } & 21 & +24 & $1 / 64$ & $1: 200$ \\
\hline & 22 & +48 & $1 / 64$ & $1: 200$ \\
\hline
\end{tabular}

* MLD : $0.5 \mathrm{mg} / 0.5 \mathrm{ml}$
毒 素 攻 撃*

\begin{tabular}{|c|c|c|c|c|}
\hline 免 疫 群 & $\begin{array}{c}\text { ウサギ } \\
\text { No }\end{array}$ & $\begin{array}{l}\text { 死亡およ } \\
\text { び 時 間 }\end{array}$ & $\begin{array}{l}\text { 攻撃時 } \\
\text { 抗毒価 }\end{array}$ & $\begin{array}{l}\text { 攻撃 時 } \\
\text { 凝集 価 }\end{array}$ \\
\hline \multirow{4}{*}{ 死菌免疫群 } & 6 & 生 & $2^{\mathrm{u}}$ & $1: 6,400$ \\
\hline & 8 & 生 & 2 & $1: 6,400$ \\
\hline & 9 & 生 & 2 & $1: 6,400$ \\
\hline & 19 & 生 & 4 & $1: 6,400$ \\
\hline \multirow{2}{*}{ トキソイド } & 13 & 生 & 4 & $1: 1,600$ \\
\hline & 14 & 生 & 2 & $1: 1,600$ \\
\hline 免 疫 群 & 15 & 生 & 4 & $1: \quad 800$ \\
\hline \multirow{2}{*}{ 生菌免疫群 } & 19 & 生 & 2 & $1: 3,200$ \\
\hline & 20 & 生 & 4 & $1: 6,400$ \\
\hline 無 処 置 群 & 23 & +5 日 & $1 / 64$ & $1: \quad 200$ \\
\hline
\end{tabular}

* MLD : $1: 4 / 0.5 \mathrm{ml}$

表 4 生菌および毒素攻撃の耐過ウサギの抗体価

\begin{tabular}{|c|c|c|c|c|c|c|}
\hline 免疫群 & 攻撃区分 & $\begin{array}{c}\text { ウサ } \\
\text { No }\end{array}$ & $\begin{array}{l}\text { 追 兔一4 } \\
\text { 抗 毒 価 } \\
\text { (攻撃前) }\end{array}$ & $\begin{array}{l}\text { 抗 毒 価 } \\
\text { (攻撃後) }\end{array}$ & $\begin{array}{l}\text { 追 } \text { 兔一 } 4 \\
\text { 㠜 集 価 } \\
\text { (攻 撃 前) }\end{array}$ & $\begin{array}{l}\text { 凝 集 価 } \\
\text { (攻 揧-後) }\end{array}$ \\
\hline \multirow{2}{*}{ 死 } & \multirow{3}{*}{$\begin{array}{l}\text { 生 } \\
\text { 菌 } \\
\text { 攻 } \\
\text { 撃 }\end{array}$} & 2 & $4^{\mathrm{u}}$ & $8^{\mathrm{u}}$ & $1: 6,400$ & $1: 1,2800$ \\
\hline & & 3 & 4 & 8 & $1: 6,400$ & $1: 1,2800$ \\
\hline 菌 & & 5 & 2 & 4 & $1: 6,400$ & $1: 6,400$ \\
\hline 免 & 毒 & 6 & 2 & 2 & $1: 6,400$ & $1: 6,400$ \\
\hline 疫 & 素 & 8 & 2 & 2 & $1: 6,400$ & I : 1,2800 \\
\hline \multirow{2}{*}{ 群 } & 攻 & 9 & 2 & 4 & $1: 6,400$ & $1: 1,2800$ \\
\hline & 揧 & 10 & 4 & 4 & $1: 6,400$ & $1: 1,2800$ \\
\hline \multirow{3}{*}{$\begin{array}{l}\text { 卜ド } \\
\text { 毛兔 } \\
\text { 疫 } \\
\text { イ群 }\end{array}$} & 毒 & 13 & 2 & 8 & $1: 1,600$ & $1: 1,600$ \\
\hline & 素 & 14 & 1 & 2 & $1: 1,600$ & $1: 1,600$ \\
\hline & 擊 & 15 & 2 & 4 & $1: \quad 800$ & $1: \quad 800$ \\
\hline \multirow{3}{*}{$\begin{array}{l}\text { 告 } \\
\text { 菌 } \\
\text { 免 } \\
\text { 疫 } \\
\text { 群 }\end{array}$} & 生菌攻撃 & 18 & 8 & 8 & $1: 6,400$ & $1: 1,2800$ \\
\hline & \multirow{2}{*}{ 毒素攻撃 } & 19 & 2 & 4 & $1: 3,200$ & $1: 3,200$ \\
\hline & & 20 & 4 & 8 & $1: 6,400$ & $1: 6,400$ \\
\hline
\end{tabular}

しそその過半数は最強の陽性を示した。またこの時期の 血中抗体価はいずれも低く末だ上昇の途にあつた。

免疫ウサギ血清のマウスに対する感染防禦能 : 次に免 疫 6 週（追加免疫 3 回後）のウ音ギの血清の抗体価は表 2 に示されたように抗毒素価は $2 \sim 8 \mathrm{u}$, 凝集素価は 1 : 800 1：3200 に上昇していたが，それぞれのウサギの血 清 $0.25 \mathrm{ml}$ 飞込宮株 $1 \mathrm{mg}(2 \mathrm{mld})$ を加光, $37^{\circ} \mathrm{C} 1$ 時間 放置後に 2 匹ずつのマウスの腹腔に注射したが血清の感
染防禦機能は認められずマウスはすべて死亡した。 免疫ウサギの感染防禦能および毒素中和能 : 次に前記 の免疫ウ开ギを 2 群にわけ，1群は前記込宮株毒素の最 小致死量を耳静脈々 注射し, 他の 1 群は生菌 $2 \mathrm{mg} / 0.5$ $\mathrm{ml}$ を注射した。実験成績は表 3 に示された通りで毒素 攻撃群の免疫ウサギはすべて生存したが，菌攻撃をらけ た群のウサギの過半数は死亡した。これ等の攻撃に耐過 したウサギの血中抗体価は表 4 に示されているが，攻撃 
前のそれに比して著しい上昇がみとめられた。また皮内 反応は生菌攻撃のみに上昇がみられた。

考察

以上の成績から皮内反応は生菌処置の場合が最も早期 に且つ最強の反応を示し，ワクチンがこれにつぎ，トキ ソイドが最もおくれ，また陽性度も低い傾向がみられ た。血中抗体価の上昇は皮膚反応の上昇よりおくれてい るが, 凝集素価はワクチンおよび生菌免疫の場合に高く 抗毒素価はトキソイド免疫の場合に高かつた。

次にこれ等の免疫血清はマウスに対する感染防禦能は もつていなかつたが，それ等のウサギが毒素攻撃に耐え 且つ生菌攻撃に対しては約半数しか防禦し得なかつた点 から考えて, 菌感染の要因は単に毒素のみによるもので ない事がうかがわれる。すなわち菌増殖の因子は単に $\alpha$ 毒素だけではなく他にも求められなければならない。ま た免疫血清の被仂的な防禦能が非常に貧弱であるとすれ ば，免疫された細胞の関与，あるいは細胞性の免疫が次 に考えられなければならない。

\section{総括}

ウサギの皮下にクロトン油による無菌膿場を形成させ ブドウ球菌を接種し，週を追つて皮内反応と血中抗体価 の推移を追及した。対照としてトキンイド，ワクチンが 生菌とおきかえられた。生菌およびワクチン処置の場合
には皮膚反応の亢進は血中抗体中の上昇より早く起つた が，トキソイド処置の場合には逆であつた。

次に抗体価の上昇した血清のブドウ球菌マウス腹腔内 攻撃に対する防禦能はみられなかつた。またこれ等のウ サギは $\boldsymbol{\alpha}$ 毒素攻擊にはよく耐えたが，菌攻撃に対しては わずかな防禦が示されたに過ぎなかつた。

\section{文献}

1) Panton. P, N., \& Valentine, E. C. O : Staphylococcal infection and reinfection. : Brit. J. Exp. Path., 10, 257-262, 1929.

2) Boe, J., : Investigations on the inportance of bacterial allergy for the developement of cutaneous infection due to staphylococci. : Acta. Dermat. Venerial., 26, 111-136, 1945.

3) Forney; J. E., : Tee sensitization of guinea pigs to micrococcus pyogenes var aureus in the presence of the "wax" of acid-fast bacilli. : Am. Rev. Tuberc., 69, 241-246, 1954.

4) Prigal, S. J. and Dubos, J. R. : Effect of allergic shock on fast of staphylococci in the organ of mice. : Proc. Soc. Exp. Biol. 93, 340-343, 1956.

5）沢井芳男, 石井卓弥, 伊藤正次郎 : ブドウ球菌の マウス腹腔内感染におよぼす抗血清ならびに能動 免疫の影響について：日本細菌学雑誌，20,239242,1965

\title{
Studies on the Immunity in Intracutaneous Infection of Rabbits by Staphylococcus aureus \\ 1. On the Relationship Between Dermal Reaction and Antibody in Intracutaneous Injection
}

\author{
Yoshio SAWAI and Takuya ISHII \\ Laboratory of Biological Products, Institute for Infectious Diseases, University of Tokyo
}

Rabbits were treated by live culture, vaccine or toxoid of staphylococcus. Then the dermal reaction by toxoid or vaccine, antitoxic antibody and agglutinin were tested. Promotion of dermal reaction proceeded the increase of antibody when rabbits treated by live cocci or vaccine whereas the latter prceeded by toxoid treatment.

The serum of high antitoxic titer failed to protect mice from death caused by the intraperitoneal infection of the cocci.

Those immunized rabbits rarely showed protection to the intravenous challenge of cocci, although they were resistant for the $\alpha$-toxin. 